\title{
A EuroHOPE kutatási program módszertana
}

\author{
Belicza Éva dr. ${ }^{1}$ - Mihalicza Péter ${ }^{2}$ - Lám Judit dr. ${ }^{1}$ - Surján Cecília ${ }^{1,2}$ \\ Semmelweis Egyetem, ${ }^{1}$ Egészségügyi Menedzserképző Központ, \\ ${ }^{2}$ Doktori Iskola, Budapest
}

\begin{abstract}
A European Health Care Outcomes, Performance and Efficiency kutatást az Európai Unió 7. keretprogramja finanszírozta 2010-2013 között. Ennek keretében olyan módszertan került kialakításra, amely lehetővé tette a közremúködő hét országban a regulárisan gyüjtött adatok alapján az ellátás elemzését és az eredmények egymással történő összehasonlítását öt, társadalmilag és gazdaságilag is jelentős teherrel járó diagnóziscsoportban. A szerzők ismertetik a módszertani fejlesztés fóbb területeit, így 1 . a módszertani alapelveket; 2 . az elérhető adatbázisok és az alkalmazott kódrendszerek felmérését; 3. az elemzendő események meghatározását; 4 . az elemzések és az indikátorok kialakításának általános szempontjait; 5. a konkrét adatgyújtési, -feldolgozási és -elemzési módszertan kidolgozását; 6. a kockázatkiigazítási módszereket és 7. a standardizált adatbázis kialakítását. A közfinanszírozott ellátás minden betegére, ellátási eseményére kiterjedő adatbázisok kimeríthetetlen és gazdag adatforrásként szolgálhatnak a döntéshozóknak, ellátóknak, kutatóknak egyaránt. A képzett indikátorok eredményei kiindulópontként szolgálnak a kiváltó okok feltárásához és az ezen okok kezelését célzó intézkedések meghatározásához. Orv. Hetil., 2016, 157(41), $1619-1625$.
\end{abstract}

Kulcsszavak: adatbázis, minőségi indikátorok, kockázatokra történő kiegyenlítés, módszerek

\section{Methods of the EuroHOPE research program}

The European Health Care Outcomes, Performance and Efficiency research was financed by the European Union between 2010 and 2013. In this program a new methodology was developed which made the analysis of regularly collected data and international benchmarking of the healthcare results of 5 socially and economically critical diagnosis group between the 7 participant countries possible. This paper presents the most important areas of the development, such as (1) the principles of the methodology, (2) the definition of available databases, code systems, (3) the events to be analysed, (4) the general rules of analyses and indicator development, (5) the exact methodology of data collection, processing, and analysis, (6) the methods of risk adjustment, (7) and the development of the standardised database. The databases which include all information of all patients and healthcare activities serve as perfect inexhaustible data sources for decision makers, healthcare personnel, and researchers. The indicator results of this program serve as starting point for further root cause analysis and development measures based on the results of the abovementioned analyses.

Keywords: database, quality indicators, risk adjustment, methods

Belicza, É., Mihalicza, P., Lám, J., Surján, C. [Methods of the EuroHOPE research program]. Orv. Hetil., 2016, 157(41), 1619-1625.

(Beérkezett: 2016. július 11.; elfogadva: 2016. augusztus 11.)

\begin{abstract}
Rövidítések
ÁEEK = Állami Egészségügyi Ellátó Központ; AMI = akut myocardialis infarctus; ATC = gyógyszervegyületek osztályozási rendszere (anatómiai, terápiás és kémiai osztályozási rendszer) $; \mathrm{BC}=$ (breast cancer) emlörák; BRIDGE Health = BRidging Information and Data Generation for Evidence-based Health policy and research; CHESS = Centre for Health and Social Economics, National Institute for Health and Welfare, Helsinki, Finnország; DRG = diagnosis-related group (Magyarországon HBCs = homogén betegségcsoport); ESKI = Egészségügyi Stratégiai Kutatóintézet; EuroHOPE = Euro-
\end{abstract}

pean Health Care Outcomes, Performance and Efficiency; GYEMSZI = Gyógyszerészeti és Egészségügyi Minőség- és Szervezetfejlesztési Intézet; HIP = (hip fracture) csípőtáji törés; OECD = Organisation for Economic Co-operation and Development; OEP = Országos Egészségbiztosítási Pénztár; STR $=$ stroke; Stata $=$ adatelemző és statisztikai szoftver; taj $=$ társadalombiztosítási azonosítójel; TTT = a készítmény azonosítására képzett, OEP által használt kód; VLBW = (very low birth weight and preterm infants) nagyon alacsony születési súlyú újszülöttek és koraszülöttek; WP = (work package) munkacsomag 
A European Health Care Outcomes, Performance and Efficiency (EuroHOPE) kutatást az Európai Unió 7. keretprogramja finanszírozta 2010-2013 között. A négyéves időtartamú projektet a finn National Institute for Health and Welfare (THL) keretein belül múködő Centre for Health and Social Economics (CHESS) tervezte és irányította 7 konzorciumi partner közremúködésével (1. táblázat). A projektbe olyan országokat toboroztak, ahol vannak úgynevezett adminisztratív, rendszeresen gyüjtött, kutatás céljára elérhető igénybevételi és halálozási adatok, és ezen adatbázisok a betegek nyomon követéséhez egymással összekapcsolhatók. A résztvevők így a projektet vezető Finnország mellett Hollandia, Magyarország, Olaszország, Norvégia, Skócia és Svédország voltak.

A EuroHOPE projekt általános célja az volt, hogy létező adatbázisokra támaszkodva, az ellátás teljes folyamatára vonatkozóan áttekintse és összehasonlítsa, valamint felmérje az eredményességben és az ellátási költségekben fellelhető különbségeket a következő 5, gazdaságilag is jelentős betegségcsoportban: akut myocardialis infarctus (AMI), stroke (STR), csípőtáji törés (HIP), emlőrák (BC) és nagyon alacsony születési súlyú újszülöttek és koraszülöttek (VLBW) [1]. A hazai konzorciumi partner, a Semmelweis Egyetem, mind az öt diagnóziscsoport munkájában részt vett az AMI munkacsomag (WP) szakmai vezetése mellett.

A projekt specifikus céljai a következők voltak [1, 2]:

- Olyan módszerek kidolgozása a meghatározott betegségcsoportok ellátási eredményeinek és költségeinek mérésére, amelyeket rutinszerúen lehet alkalmazni a teljes ellátási folyamatra (nem csupán az egyes ellátási epizódokra vagy eljárásokra).

- Ajánlás megfogalmazása az Európai Unióban rutinszerüen gyújtött adatokra támaszkodó, a teljesítmények mérésére és folyamatos monitorozására alkalmas indikátorlistára.

- Nemzetközi, adminisztratív adatbázisokra támaszkodó, összehasonlítást célzó, egészségügyi ellátásra vonatkozó kutatások számára módszerek kidolgozása.

- Az ellátás eredményességének és a költségek (vagy más forrásfelhasználási mérések) közötti kapcsolatok vizsgálata - a hatékonyság mérése - az európai országok, az országokon belüli területi egységek és a szolgáltatók között.

- Az ellátás eredményességének és költségeinek különbségeit magyarázó okok feltárása.

- Ajánlás megfogalmazása a nemzeti szintú adatbázisok adattartalmára és a kimeneti mérésekre a teljesítmények folyamatos monitorozásának fejlesztése érdekében.

- Európai szintű benchmarking létrehozása a kimenetek és a költségek vonatkozásában, amelyek lehetővé teszik a döntéshozóknak és az egészségügyi szakembereknek, hogy tanuljanak a legjobb gyakorlatokból.

Dolgozatunk célja a projekt általános módszertanának ismertetése. Azokat a módszertani kérdéseket emeltük

\section{1. táblázat |A EuroHOPE kutatásban közremúködő intézmények}

- National Institute for Health and Welfare, Helsinki, Finnország

- Centre for Research on Health and Social Care Management, Università Commerciale Luigi Bocconi, Milánó, Olaszország

- Semmelweis Egyetem, Egészségügyi Menedzserképző Központ, Budapest, Magyarország

- National Institute of Public Health and the Environment, Amszterdam, Hollandia

- University of Oslo, Institute of Health Management and Health Economics, Oslo, Norvégia

- Ragnar Frisch Centre for Economic Research, Oslo, Norvégia

- University of Edinburgh, Skócia

- Medical Management Centre, LIME, Karolinska Institutet, Stockholm, Svédország

2. táblázat |A módszertani fejlesztés fó lépései

1. A célok teljesítéséhez szükséges módszertani alapelvek meghatározása és elfogadása.

2. Az elérhető adatbázisok és az alkalmazott kódrendszerek felmérése a közremúködő országokban.

3. Az elemzendő események meghatározása.

4. Az elemzések és az indikátorok kialakításának általános szempontjai.

5. Az adatgyüjtési, -feldolgozási és -elemzési módszertan kidolgozása, elemzendő indikátorok definiálása munkacsomagonként.

6. Kockázatkiegyenlítési módszerek kialakítása.

7. Standardizált adatbázis kialakítása.

ki, amelyek a jelen lapszámban megjelenő AMI, STR, HIP és VLBW diagnóziscsoportokkal kapcsolatos közleményeink értelmezéséhez szükségesek. A EuroHOPE kutatás egyéb területeit a nemzetközi publikációkból [3-12] és a kutatás honlapjáról lehet megismerni (http://www.eurohope.info). Az egyes diagnóziscsoportok specifikus módszertani jellemzőit a témát ismertető dolgozatokban közöljük.

\section{Módszertan}

A projekt céljainak teljesülése szempontjából kiemelt fontosságú volt egy olyan módszertan kidolgozása, amely a különböző adatgyüjtési és kódrendszerekkel dolgozó országok eredményeit tudományos igényességgel teszi összehasonlíthatóvá.

A részletes módszertant a CHESS korábbi, hasonló jellegű munkáira [13] támaszkodva, rendszeres találkozók és telefonkonferenciák során dolgoztuk ki (2. táblázat).

\section{A célok teljesitéséhez szükséges módszertani alapelvek meghatározása és elfogadása}

A módszertani alapelvek meghatározásának két kiindulópontja volt: az összehasonlíthatóság biztosítása és a saját adatok védelme. Ennek mentén a következő döntések születtek: 
Az eredmények releváns összehasonlításához standardizálni kell az adatgyújtést és az -elemzést. Ezen belül szükséges az adatelemek definiálása, az alkalmazandó kódok meghatározása, országonként eltérő kódrendszerek esetén az illeszkedés biztosítása. Döntés született arról, hogy

a) csak olyan adatelemeket veszünk figyelembe az indikátorok képzése során, amelyek a közremúködő országok többségében elérhetők;

b) a feldolgozás és az elemzés standardizálásához egységes adatstruktúra készül, és minden részt vevő ország ebbe az adatstruktúrába rendezi a saját adatait;

c) a számításokat a Stata adatbázis-kezelő és statisztikai szoftverhez a CHESS által készített feldolgozóprogramok segítségével minden részt vevő ország önmaga végzi el.

\section{Az elérheto" adatbázisok és az alkalmazott kódrendszerek felmérése a közremüködö országokban}

Kérdőíves felmérés zajlott a közremúködő országokban az elérhető adatbázisokra, alkalmazott kódrendszerekre és az elemezhető évekre vonatkozóan.
A részt vevő országok mindegyikében elérhetőek voltak a fekvőbeteg- és a járóbeteg- (ambuláns) szakellátásra vonatkozó állományok. Betegszintű alapellátási, otthoni ápolási és egyéb szolgáltatói adatok kevés helyen álltak rendelkezésre, így ezeket az adatforrásokat a továbbiakban nem vettük figyelembe. Betegszintű gyógyszerállománnyal csak Skócia nem rendelkezett (3. táblázat).

A betegek azonosítására Hollandia és az újszülöttek esetében Magyarország kivételével mindenütt egyedi azonosítók alkalmazására volt lehetőség. Hollandiában egyéb jellemzők (születési idő, nem, postai irányítószám) alapján sztochasztikus modell segítségével, körülbelül 85\%-os megfelelőséggel kapcsolták össze az ellátási eseményeket. A magyar újszülöttek adatainak összekapcsolásáról jelen lapszám vonatkozó cikkében közlünk részleteket.

A betegségek kódolása minden partnernél a Betegségek Nemzetközi Osztályozása (BNO) 9-es vagy 10-es verziója alapján történt, és minden ország az ATC kódrendszert alkalmazta a gyógyszerek azonosításához. A hazai vényforgalmi állományban a kiváltott gyógyszerek azonosításához használt TTT-kódok és ATC-kódok közötti megfeleltetést az Országos Egészségbiztosítási Pénztár (OEP) honlapján elérhető információk felhasználásával határoztuk meg.

3. táblázat |A közremúködő országok adatbázisai, a rekordok összekapcsolási lehetősége és az alkalmazott kódrendszerek

\begin{tabular}{|c|c|c|c|c|c|c|c|c|c|}
\hline \multirow[t]{2}{*}{ Ország } & \multicolumn{7}{|c|}{ Állományok elérhetősége } & \multicolumn{2}{|c|}{ Alkalmazott kódok } \\
\hline & $\begin{array}{l}\text { Kórházi } \\
\text { elbocsátások }\end{array}$ & $\begin{array}{l}\text { Szülészeti } \\
\text { események } \\
\text { regisztere }\end{array}$ & $\begin{array}{l}\text { Vényköteles } \\
\text { gyógyszerek }\end{array}$ & Halálozás & $\begin{array}{l}\text { Egyéb } \\
\text { nyilvántartások }\end{array}$ & Lefedettség & $\begin{array}{l}\text { Betegszintű } \\
\text { Össze- } \\
\text { kapcsolás* }\end{array}$ & $\begin{array}{l}\text { Betegség } \\
\text { kódjai }\end{array}$ & $\begin{array}{l}\text { Beavatkozások } \\
\text { kódjai }\end{array}$ \\
\hline Finnország & Igen & Igen & Igen & Igen & $\begin{array}{l}\text { Koraszülöttek, } \\
\text { fejlődési } \\
\text { rendellenes- } \\
\text { ségek }\end{array}$ & Országos & $\begin{array}{l}\text { Egyedi } \\
\text { azonosítóval }\end{array}$ & ICD-10 & NCSP \\
\hline Hollandia & Igen & Igen & Igen & Igen & Nincs & $\begin{array}{l}\text { Kórházi } \\
\text { részvétellel }\end{array}$ & $\begin{array}{l}\text { Egyéb } \\
\text { módon }\end{array}$ & ICD-9 & $\begin{array}{l}\text { ICPM } \\
\text { nemzeti } \\
\text { adaptálása }\end{array}$ \\
\hline Magyarország & Igen & Igen & Igen & Igen & Nincs & Országos & $\begin{array}{l}\text { Egyedi } \\
\text { azonosítóval }\end{array}$ & ICD-10 & $\begin{array}{l}\text { ICPM } \\
\text { nemzeti } \\
\text { adaptálása } \\
(\text { OENO) }\end{array}$ \\
\hline Norvégia & Igen & Igen & Igen & Igen & $\begin{array}{l}\text { Csípőtáji } \\
\text { törések }\end{array}$ & Országos & $\begin{array}{l}\text { Egyedi } \\
\text { azonosítóval }\end{array}$ & ICD-10 & NCSP \\
\hline Olaszország & Igen & $\begin{array}{l}\text { Lazio } \\
\text { (Róma) } \\
\text { tartomány- } \\
\text { ban }\end{array}$ & $\begin{array}{l}\text { Néhány } \\
\text { régióban } \\
\text { csak kor- } \\
\text { látozottan }\end{array}$ & Igen & Nincs & $\begin{array}{l}\text { Néhány } \\
\text { tartomány }\end{array}$ & $\begin{array}{l}\text { Egyedi } \\
\text { azonosítóval }\end{array}$ & ICD-9-CM & ICD-9-CM \\
\hline Skócia & Igen & Igen & Nincs & Igen & $\begin{array}{l}\text { Szülészeti } \\
\text { ellátás }\end{array}$ & Országos & $\begin{array}{l}\text { Egyedi } \\
\text { azonosítóval }\end{array}$ & ICD-10 & OPCS 4.5 \\
\hline Svédország & Igen & Igen & Igen & Igen & Nincs & Országos & $\begin{array}{l}\text { Egyedi } \\
\text { azonosítóval }\end{array}$ & ICD-10 & NCSP \\
\hline
\end{tabular}

*Az újszülöttek regiszterben található rekordjainak összekapcsolása nélkül.

ICD = International Classification of Diseases (BNO); ICD-9-CM = 9-es BNO klinikai modifikációja; ICPM = International Class of Procedures in Medicine; NCSP = Nordic Classification of Surgical Procedures; OENO = Orvosi Eljárások Nemzetközi Osztályozása (ICPM); OPCS = Classification of Interventions and Procedures. 
A beavatkozások kódrendszerei országonként jelentős változékonyságot mutatnak. Az északi országok közös kódrendszert alkalmaznak, az olaszok a BNO klinikai modifikációját, míg Magyarország, Skócia és Hollandia egyedi kódrendszereket. A figyelembe veendő beavatkozások, sebészeti eljárások kódjait szöveges leírásuk alapján minden ország saját hatáskörben határozta meg klinikus szakértők közremúködésével (3. táblázat).

\section{Az elemzendó események meghatározása}

Minden WP-ben definiáltuk az elemzésbe bevonandó ellátási eseményt, eseménysorozatot. AMI, STR és HIP esetén ennek logikája azonos volt. Az esemény kezdete azon kórházi felvétel időpontja volt, ahol az ápolást indokló fódiagnózis a WP által meghatározott kódok valamelyikét tartalmazta. Bevonási kritérium volt, hogy a megelőző 12 hónapban a betegnek az adott diagnóziscsoporthoz tartozó fődiagnózissal ne legyen ismert kórházi ellátási eseménye. A VLBW-csoportban az úgynevezett indexesemény kezdete a megszületés napja volt. További bevonási kritériumok meghatározott betegjellemzőket fogalmaztak meg. A követhetőség érdekében kizárási kritérium volt, ha a beteg nem rendelkezett az adott ország állampolgárságával.

Az index kórházi ellátási esemény nem csupán az elsó osztályos felvételt tartalmazza, hanem minden olyan további osztályos vagy követő kórházi felvételt is magában foglal, amikor az elbocsátást követően az új felvételi esemény aznap vagy másnap történt (1. ábra).

\section{Az elemzések és az indikátorok kialakitásának általános szempontjai}

Az elemzések előzetes megtervezése fontos lépés volt a gyưjtendő adatok körének meghatározásához. Követési időszaknak az indexfelvételtől számított egy évet vettük figyelembe. Indikátorként az ellátás folyamatjellemzőit (kórházi felvételek időtartama, szakterülete, beavatkozások típusa, időpontja, kiváltott gyógyszerek és kiváltási időpontjuk), kimeneti mutatókat (szövődmények, viszszavételek, halálozás) és költségekhez kötődő mutatókat definiáltunk. Az indikátorokat országos, regionális és intézményi szinten határoztuk meg. A betegek a lakóhelyük szerinti területi egységekbe kerültek besorolásra. Magyarországon megyei bontást használtunk, a besorolás a betegek irányítószáma alapján történt.

A komorbiditás számolásának két módját dolgoztuk ki. Az első esetben a megelőző egy év kórházi felvételei során rögzített diagnózisokat vettük figyelembe, a második esetben ezek mellett az ugyanezen időszakban kiváltott, adott betegség kezelésére specifikus gyógyszerek alapján következtettünk a komorbiditás meglétére. A járóbeteg-ellátás diagnózisait nem vettük figyelembe, mivel rögzítési gyakorlatuk országonként jelentősen eltér. A komorbiditáshoz figyelembe vett diagnózisokat, kódjukat, illetve a diagnózishoz kapcsolt gyógyszerek azonosításához alkalmazott ATC-kódokat minden WP esetén részletes táblák tartalmazzák (4. táblázat).

\section{Munkacsomagonkénti adatgyüjtési, -feldolgozási és-elemzési módszertan kidolgozása}

Minden WP saját adatgyüjtési és -feldolgozási protokollt dolgozott ki, amit az anyagok tárolására létrehozott internetes felületen lehetett naprakész formában elérni. A protokollok a következő fő fejezeteket tartalmazzák: - a WP célja és szereplői,

- az alkalmazott fogalmak definíciója,

- esetek beválogatási és kizárási kritériumai, - elemzéshez felhasznált komorbiditás, - indikátorok,

ljes ellátási esemény
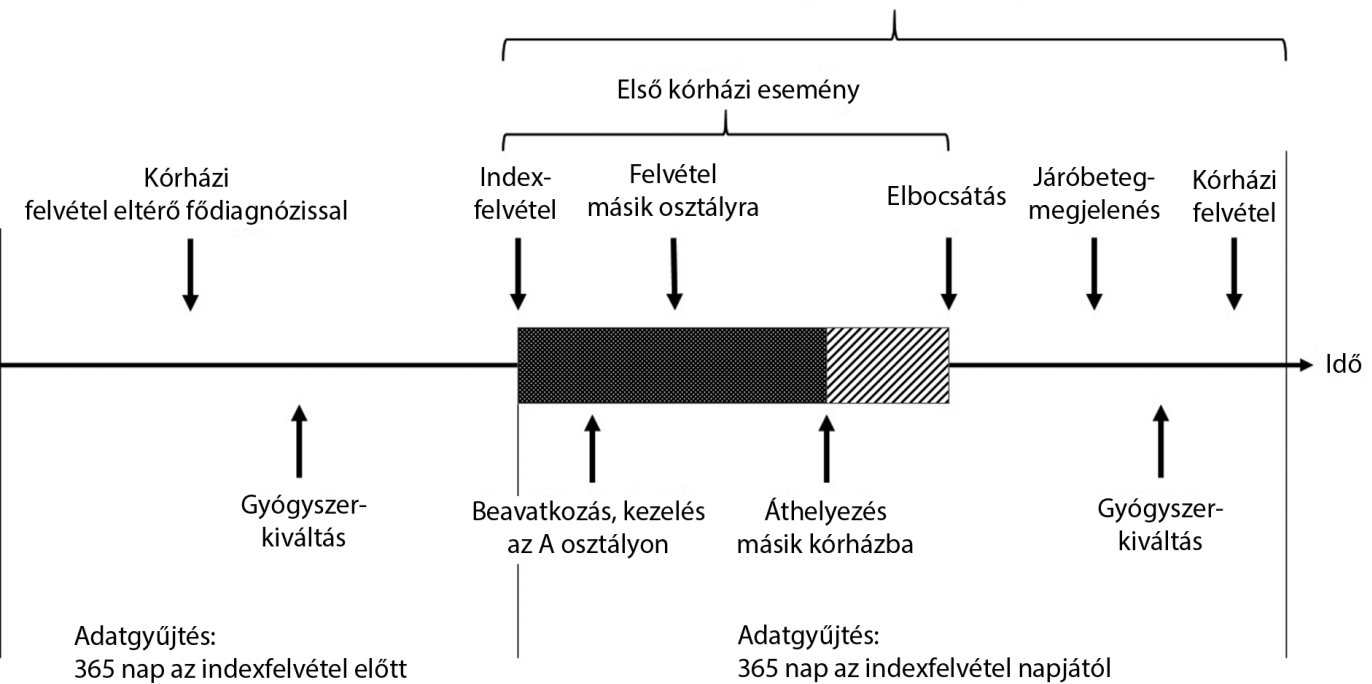

365 nap az indexfelvétel napjától 
- kockázatra történő kiegyenlítés módszerei,

- szakirodalmi források,

- kódtáblázatok.

A végleges protokollok (discussion papers) a projekt honlapjáról nyilvánosan elérhetők (http://www.eurohope.info).

\section{Kockázatkiegyenlitési módszerek kialakitása}

Az indikátorok eredményeit sokszor nem csupán az ellátás mikéntje, hanem az ellátott betegek saját jellemzői befolyásolják. A különböző betegpopulációkra vonatkozó indikátorértékek releváns összehasonlításához ezért olyan eljárást kell alkalmazni, amely kiküszöböli a betegek kockázati összetételében meglévő különbségeket. A kockázatok kiegyenlítéséhez olyan tényezőket tudtunk figyelembe venni, amelyekhez az adatok rendelkezésre álltak. Három, különböző kockázati jellemzőket tartalmazó modell került meghatározásra:

1. életkor, nem;

4. táblázat $\mid$ Kockázati tényezőként figyelembe vett betegségek, valamint az adott betegségben specifikus gyógyszerek az akut myocardialis infarctus, stroke és csípőtáji törések munkacsomagokban

\begin{tabular}{lll}
\hline Diagnózis & BNO-10 & ATC-kód \\
\hline Magas vérnyomás & $\mathrm{I10*-I15*}$ & $\mathrm{C} 03^{*}, \mathrm{C} 07^{*}$ \\
& & (ha nincs sem \\
coronariabetegség, & sem pitvari fibrilláció), \\
& & $\mathrm{C} 08^{*}, \mathrm{C} 09^{*}$ \\
\hline
\end{tabular}

\begin{tabular}{lll}
\hline Coronariabetegség & $\mathrm{I} 20^{*}-\mathrm{I} 25^{*}$ & N/A \\
\hline Pitvari fibrilláció & $\mathrm{I} 48^{*}$ & N/A \\
\hline
\end{tabular}

\begin{tabular}{lll}
\hline Szívelégtelenség & $\mathrm{I} 50^{*}$ & $\mathrm{~N} / \mathrm{A}$ \\
\hline Cukorbetegség & $\mathrm{E} 10^{*}-\mathrm{E} 14^{*}$ & $\mathrm{Al0A}{ }^{*}, \mathrm{Al0B}{ }^{*}$ \\
\hline Atherosclerosis & $\mathrm{I70*}$ & $\mathrm{N} / \mathrm{A}$ \\
\hline Daganat & $\mathrm{C} 00^{*}-\mathrm{C} 99^{*}$ & $\mathrm{~L} 01 *$ kivéve
\end{tabular}

\begin{tabular}{lll}
\hline Daganat & $\mathrm{C} 00^{*}-\mathrm{C} 99^{*}$, & L01*, kivéve \\
& D00*-D09* & L01BA01 \\
\hline COPD és asztma & J44*-J46* & R03* \\
\hline
\end{tabular}

\begin{tabular}{lll} 
COPD és asztma & $\mathrm{J44}^{*}-\mathrm{J} 46^{*}$ & $\mathrm{R} 03 *$ \\
\hline Demencia & $\mathrm{F} 00^{*}-\mathrm{F} 03^{*}, \mathrm{G} 30 *$ & $\mathrm{~N}^{*} 6 \mathrm{D}^{*}$ \\
\hline Depresszió & $\mathrm{F} 32^{*}-\mathrm{F} 34^{*}$ & $\mathrm{~N}^{*} 6 A^{*}$ \\
\hline
\end{tabular}

Parkinson-kór G20* N04B*

Mentális betegségek F20*-F31* N05A*, kivéve

N05AB01 és

N05AB04, és nincs

demencia

\begin{tabular}{lll}
\hline Veseelégtelenség & $\mathrm{N18*}$ & $\mathrm{N} / \mathrm{A}$ \\
\hline Alkoholizmus & $\mathrm{F} 10^{*}-\mathrm{F} 19^{*}$ & $\mathrm{~N} / \mathrm{A}$ \\
\hline Stroke $^{+}$ & $\mathrm{I} 60^{*}, \mathrm{I} 61^{*}, \mathrm{I} 63^{*}$, & $\mathrm{N} / \mathrm{A}$ \\
& $\mathrm{I} 64^{*}, \mathrm{G} 45^{*}$ & \\
\hline Reumabetegségek $^{++}$ & $\begin{array}{l}\mathrm{M} 05^{*}, \mathrm{M}^{*}, \\
\mathrm{M} 45^{*}\end{array}$ & $\mathrm{~N} / \mathrm{A}$ \\
& & \\
\hline
\end{tabular}

+ Stroke-munkacsomag kivételével.

++ Csak a csípőtáji törések munkacsomagban.

* A kód többi karaktere bármi lehet.

$\mathrm{N} / \mathrm{A}=$ nem értelmezhető.
2. életkor, nem, komorbiditás az indexfelvételt megelőző év kórházi felvételei alapján, az indexfelvételt megelőző évben kórházban töltött napok száma;

3. életkor, nem, komorbiditás az indexfelvételt megelőző év kórházi felvételei és a kiváltott gyógyszerek alapján, az indexfelvételt megelőző évben kórházban töltött napok száma.

A kockázatok kiegyenlítésére dichotom (kétértékü) változók esetében (például halálozás) többváltozós logisztikus regressziót, folytonos változók esetén (például költségek) lineáris regressziós modellt, diszkrét változókra (például ápolási idő) negatív binomiális modellt alkalmaztunk [13]. Mivel a nem és az életkor minden országban elérhető jellemző volt, az 1. modellel minden érintett indikátornál lehetett kockázatkiegyenlítést végezni. A 2. és 3. modell alkalmazását a közremúködő országok adatelérhetősége korlátozta (3. táblázat). Az egyes modellek összehasonlító elemzésével önálló tanulmány foglalkozik [14].

\section{Standardizált adatbázis kialakitása}

A CHESS irányításával minden WP-ben meghatározott adatstruktúra került kidolgozásra. A közremúködő országok saját adataikból ennek megfelelóen állították elő a standard adatbázist. A hazai adatokat az Egészségügyi Stratégiai Kutatóintézet (ESKI, 2011-től Gyógyszerészeti és Egészségügyi Minőség- és Szervezetfejlesztési Intézet [GYEMSZI], 2014-től az Állami Egészségügyi Ellátó Központ [ÁEEK]) bocsátotta rendelkezésünkre, amely intézmény jogszabály alapján elemzési és kutatási célokra 2004-tôl kapja meg az OEP-től az igénybevételi adatokat. Az anonim taj-számokat (taj kapcsolati kód, pszeudo-taj) az OEP állítja elő mind a fekvő-, mind a járóbeteg-állományra, a halálozási dátumokat is tartalmazó úgynevezett taj-törzsre és a receptre kiváltott gyógyszerekre. Haláloki adatokat nem használtunk. A VLBW-elemzések során felhasználtuk a szülészeti események adatbázisát (Tauffer-statisztika) is (2. ábra).

A saját adatbázisok feldolgozását a CHESS által a Stata statisztikai szoftverhez készített feldolgozó és elemző programkódok futtatásával végezte minden közremúködő fél, ezzel biztosítva az egységes módszertant és az összehasonlítható adatokat. Az indikátoreredményeket a

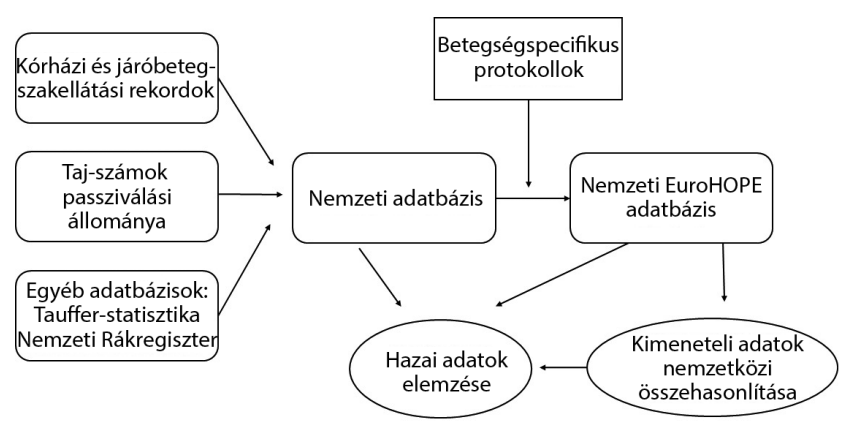

2. ábra | Magyarországi adatbázis-építés a EuroHOPE kutatásban 
Stata programok egységes adattartalommal Excel formátumban rögzítették. Ezek a nyers és a különböző kockázatkiegyenlítési módszerekkel meghatározott indikátoreredményeket tartalmazták országos, regionális és intézményi szinten egyaránt. A többváltozós regressziós elemzések magyarázó változóihoz tartozó értékek Word állományban kerültek rögzítésre. Az eredményfájlokat a közös informatikai felületre töltöttük fel, és a WP-vezetők és a közremúködő szakértők a további elemzéseket ezek alapján végezték.

\section{Eredmények}

Valamennyi diagnóziscsoporthoz elkészültek az adatfeldolgozási és -elemzési protokollok. A közremúködő országok mindegyike ezek alapján legalább egy évre vonatkozóan előállította a tervezett indikátorokat.

A projekt időtartamába egy mintaév elemzése fért bele. Közös döntés alapján ez a 2007-es év volt, illetve esetenként a 2006-2008 közötti évek adatai kerültek feldolgozásra. A magyarországi adatokat az AMI és az STR esetében több évre, a 2005-2009 közötti időszakra vonatkozóan is feldolgoztuk, a HIP-adatok 2004-2009 között állnak rendelkezésre, a VLBW-elemzés a 20062008 közötti időszakra készült el.

A EuroHOPE honlapja az eredményeket térképes ábrázolás formájában is bemutatja (http://eurohope.info). A nemzetközi összehasonlító elemzéseket számos publikációban [3-12] közöltük, a részletes publikációs jegyzék ugyancsak elérhető a EuroHOPE honlapján.

\section{Megbeszélés}

A szisztematikusan kialakított módszertan és annak következetes végrehajtása biztosította a standardizált adatbázisok kialakítását, az egységes feldolgozást és elemzést. A Stata-kódok használata gyorsan, az emberi és technikai hibák lehetőségét minimálisra csökkentve tudta az előzetesen elfogadott statisztikai elemzéseket, indikátorértékeket elóállítani. Ez a standardizáció ugyanakkor a nemzetközi összehasonlítások során némi korlátot is jelent az érdeklődő kutató számára, hiszen csak az előzetesen közösen elfogadott indikátorok váltak elérhetővé a további elemzések számára, az időközben felmerülő kérdésekre csak a saját, rekordszinten is elérhető adatok mélyebb elemzése során lehetett választ kapni.

A kutatás kereteiben adatminőség-ellenőrzés nem történt sem az egyes adatelemek validitása, sem az adattartalom teljessége szempontjából. A szakmai egyeztetések ugyanakkor felhívták a figyelmet néhány olyan adatszolgáltatási gyakorlatra, amit az indikátoreredmények értelmezése során figyelembe kell venni.

Mint említettük, néhány országban nem érdekeltek a másodlagos diagnózisok rögzítésére, erre vonatkozóan megbízhatóbb adatforrás az adott diagnózisokra specifikus, kiváltott gyógyszerek adatbázisa. Az országok többségében teljesítmény- (DRG-) alapú finanszírozás van, ami befolyásolhatja az adatrögzítési szokásokat. Gyakran hangzik el ezért ellenérvként hazánkban is, hogy a finanszírozási adatokat nem lehet elemzési célokra felhasználni [15]. Ennek ellenére ezen adatokra támaszkodóan számos publikáció jelenik meg lektorált folyóiratokban [16-21]. 2015-ben jelent meg egy kutatás, amely az OEP-jelentések és a betegdokumentáció adattartalmát vetette össze stroke-betegek esetén. A tanulmány szerint az OEP-adatlapok adattartalma megfelelő informatikai eszközök alkalmazásával és szürőfeltételek beépítésével epidemiológiai kutatások céljára alkalmas [22].

A külföldi adatbázisok teljességével kapcsolatban ismert néhány torzító tényező.

Hollandiában nem minden kórház vett részt az adatszolgáltatásban a kutatás éveiben, illetve néhány kórház nem rögzítette a beavatkozásokat. Ha az indexfelvétel előtt, illetve a késóbbi időszakban a beteg olyan kórházba került, amely nem vett részt az adatszolgáltatásban, komorbiditási adatai hiányosak lehetnek, illetve kieshetett a követésból. További torzítás a már korábban említett nem pontos betegazonosítás a rekordok összekapcsolása során. A gyógyszerekre vonatkozó információ aggregált formában a megelőző vagy követő naptári évre vonatkozik, nem a megelőző 365 vagy a követő 365 napra.

Olaszországból csak Torino és Lazio tartomány (Róma megye) vett részt a kutatásban, esetükben a bevont betegek követése nem mindig teljes. Torino kórházaiban távozáskor a betegek háromhavi gyógyszert kézhez kapnak, így a vásárolt gyógyszerek adatbázisában ezek nem jelennek meg.

Véleményünk szerint a hazai adminisztratív adatok trendelemzésre biztosan, nemzetközi összehasonlításra alapos meggondolások alapján alkalmasak. Az egészségügyi szolgáltatók kialakult adatrögzítési gyakorlatában - amennyiben az érdekeltségi viszonyok nem változnak - lényegi változás nem feltételezhető, így a trendeket ez a tényező érdemben nem befolyásolhatja. Az elemzési eredmények összevetése más releváns hazai és nemzetközi kutatási eredményekkel, népegészségügyi adatokkal támpontot adhat az alapadatok validitásának eldöntéséhez. Kutatásaink során törekedtünk releváns összehasonlítások végzésére, és nem találtunk olyan eredményeket, amelyek megkérdőjeleznék az adminisztratív adatok alkalmasságát a különböző, jelen lapszámban bemutatott diagnóziscsoportokban zajló ellátás elemzésére.

A EuroHOPE által kifejlesztett módszertan jelentős nemzetközi elismerésnek örvend. Az OECD Health Care Quality Indicators munkacsoportja minőségi indikátorai közé több, a EuroHOPE által kidolgozott indikátort is beemelt. A kidolgozott módszertan segítségével folytatódik 2015-tól a munka egy önálló WP keretében a BRIDGE-HEALTH kutatási programban, ahol három diagnóziscsoportban (AMI, STR, HIP) a 2006-2013 közötti időszakra készülnek majd elemzések dán, finn, magyar, norvég, olasz és svéd részvétellel. 
A minden betegre, ellátási eseményre kiterjedő adatbázisok kimeríthetetlen és gazdag adatforrásként szolgálhatnak a döntéshozóknak, ellátóknak, kutatóknak egyaránt. A képzett indikátorok nem minősítik az ellátást és önmagukban nem képesek az esetlegesen észlelt gyengeségek magyarázatára. Az indikátorok ugyanakkor felhívják a figyelmet azokra a területekre, amelyek további elemzést igényelnek. A szükséges intézkedéseket az oki kutatások eredményeire alapozva lehet meghatározni.

Anyagi támogatás: A szerzők a közlemény alapját képező ismeretek összegyújtéséért az Európai Unió 7. keretprogramjának 241721. számú szerződése szerint a European Health Care Outcomes, Performance and Efficiency (EuroHOPE) projekt keretében anyagi támogatásban részesültek.

Szerzői munkamegosztás: B. É.: A közlemény vázának összeállítása, a kutatás hazai irányítása, három témakörben a hazai módszertan kidolgozása. M. P.: A közlemény szakmai tartalmának kiegészítése, két témakörben a hazai módszertan kidolgozása. L. J.: A gyógyszer-alkalmazási gyakorlathoz kapcsolódó módszertani elemek kidolgozása, értelmezése, kódtáblák összeállítása. S. C.: A szakirodalmi áttekintés, részvétel az adatleválogatási módszer kidolgozásában, adatgyújtés. A cikk végleges változatát valamennyi szerző elolvasta és jóváhagyta.

Érdekeltségek: A szerzők aktívan részt vettek a 2013-ban zárult EuroHOPE kutatási projektben.

\section{Irodalom}

[1] Häkkinen, U., Iversen, T., Peltola, M., et al.: Health care performance comparison using a disease-based approach: The EuroHOPE project. Health Policy, 2013, 112(1-2), 100-109.

[2] Häkkinen, U., Iversen, T., Peltola, M., et al.: Towards explaining international differences in health care performance: results of the EuroHOPE project. Health Econ., 2015, 24(Suppl. 2), 1-4.

[3] Fattore, G., Numerato, D., Peltola, M., et al.: Variation and determinants of mortality and length of stay of very low birth weight and very low for gestational age infants in seven European countries. Health Econ., 2015, 24(Suppl. 2), 65-87.

[4] Hagen, T. P., Häkkinen, U., Belicza, É., et al.: Acute myocardial infarction, use of percutaneous coronary intervention, and mortality: A comparative effectiveness analysis covering seven European countries. Health Econ., 2015, 24(Suppl. 2), 88-101.

[5] Hagen, T. P., Häkkinen, U., Iversen, T., et al.: Socio-economic inequality in the use of procedures and mortality among AMI patients: quantifying the effects along different paths. Health Econ., 2015, 24(Suppl. 2), 102-115.

[6] Häkkinen, U., Rosenqvist, G., Iversen, T., et al.: Outcome, use of resources and their relationship in the treatment of AMI, stroke and hip fracture at European hospitals. Health Econ., 2015, 24(Suppl. 2), 116-139.

[7] Iversen, T., Aas, E., Rosenqvist, G., et al.: Comparative analysis of treatment costs in EuroHOPE. Health Econ., 2015, 24(Suppl. 2), 5-22.

[8] Malmivaara, A., Meretoja, A., Peltola, M., et al.: Comparing ischaemic stroke in six European countries. The EuroHOPE register study. Eur. J. Neurol., 2015, 22(2), 284-291.
[9] Medin, E., Goude, F., Melberg, H. O., et al.: European regional differences in all-cause mortality and length of stay for hip fracture patients. Health Econ., 2015, 24(Suppl. 2), 53-64.

[10] Numerato, D., Fattore, G., Tediosi, F., et al.: Mortality and length of stay of very low birth weight and very preterm infants: A EuroHOPE Study. PLoS ONE, 2015, 10(6), e0131685.

[11] Peltola, M., Seppälä, T. T., Malmivaara, A., et al.: Individual and regional-level factors contributing to variation in length of stay after cerebral infarction in six European countries. Health Econ., 2015, 24(Suppl. 2), 38-52.

[12] Heijink, R., Engelfriet, P., Rehnberg, C., et al.: A window on geographic variation in health care: insights from EuroHOPE. Health Econ., 2015, 24(Suppl. 2), 164-177.

[13] Häkkinen, U.: The PERFECT project: measuring performance of health care episodes. Ann. Med., 2011, 43(Suppl. 1), S1-S3.

[14] Moger, T. A., Peltola, M.: Risk adjustment of health-care performance measures in a multinational register-based study: A pragmatic approach to a complicated topic. SAGE Open Med., 2014, 2, 2050312114526589

[15] Jánosi, A., Póth, A., Zorándi, Á., et al.: Treatment of patients with myocardial infarction in Hungary on the basis of available health data. [Szívinfarktus miatt kezelt betegek ellátásának vizsgálata Magyarországon a rendelkezésre álló egészségügyi adatok alapján.] Orv. Hetil., 2016, 157(3), 89-93. [Hungarian]

[16] Belicza, É., Jánosi, A.: Study of incidence and treatment of acute myocardial infarction by evaluating the financing database: 2004-2009. [A heveny szívinfarktus előfordulásának és ellátásának vizsgálata a finanszírozási adatbázis elemzésével: 20042009.] Orv. Hetil., 2012, 153(3), 102-112. [Hungarian]

[17] Kárpáti, K., Brodszky, V., Májer, I., et al.: Incidence and costs of stroke patients in Hungary, using the data of National Health Insurance Fund. [Az akut stroke előfordulása és betegségterhe hazánkban, OEP-adatok alapján.] IME, 2007, 6(10), 41-45. [Hungarian]

[18] Tomcsányi, J., Bózsik, B., Rokszin, Gy., et al.: The prevalence of atrial fibrillation in Hungary. [A pitvarfibrilláció prevalenciája Magyarországon.] Orv. Hetil., 2012, 153(9), 339-342. [Hungarian]

[19] Nagy-Vincze, M., Bodoki, L., Griger, Z., et al.: Epidemiology of idiopathic inflammatory myopathy in Hungary. [Epidemiológiai adatok idiopathiás inflammatorikus myopathiákban Magyarországon.] Orv. Hetil., 2014, 155(41), 1643-1646. [Hungarian]

[20] Sebestyén, A., Boncz, I., Tóth, F., et al.: Evaluation of the correlation between risk factors and mortality in elderly patients with femoral neck fracture with 5-year follow-up. [Időskori combnyaktöréseket követő halálozás és kockázati tényezőik kapcsolatának értékelése 5 éves utánkövetéssel.] Orv. Hetil., 2008, 149(11), 493-503. [Hungarian]

[21] Ludwig, E., Jorgensen, L., Gray, S., et al.: Clinical burden of multi-cause and pneumococcal pneumonia, meningitis, and septicemia in Hungary. Results of a retrospective study (2006-2011). [Pneumococcus, illetve bármely kórokú pneumonia, meningitis és septikaemia miatti hospitalizáció és halálozás Magyarországon. Egy retrospektív értékelés eredménye (2006-2011).] Orv. Hetil., 2014, 155(36), 1426-1436. [Hungarian].

[22] Ajtay, A., Oberfrank, F., Bereczki, D.: Applicability of hospital reports submitted for reimbursement purposes for epidemiological studies based on the example of ischemic cerebrovascular diseases. [A kórházi adatlapok jelentéseinek alkalmazhatósága epidemiológiai elemzésekre az ischaemiás cerebrovascularis betegségek példája alapján.] Orv. Hetil., 2015, 156(38), 15401546. [Hungarian]

(Belicza Éva dr., Budapest, Kútvölgyi út 2., 1125 e-mail: belicza@emk.sote.hu) 